\title{
IMPLEMENTATION OF PREZI MEDIA TO IMPROVE UNDERSTANDING OF STUDENTS IN ENGLISH LEARNING
}

\author{
Eka Resty Novieta Sari ${ }^{(1)}$, Rizal Ula Ananta Fauzi ${ }^{(2)}$ \\ ekaresty@unipma.ac.id ${ }^{(1)}$, rizalmanajemen@gmail.com ${ }^{(2)}$ \\ Informatics Engineering Department, Faculty of Engineering \\ PGRI University of Madiun ${ }^{(1)}$ \\ Management Department, Business Economic Faculty \\ PGRI University of Madiun ${ }^{(2)}$
}

\begin{abstract}
This study aims to apply the learning model by using Prezi to improve understanding of English courses. This research was conducted at the PGRI University of Madiun in the Academic Year of 2017/2018. The research subjects were students of Primary School Teacher Education. This study uses a classroom action research design. It was used to solve learning problems in the classroom that seeks to study and reflect in depth some aspects of learning. This research was divided into two cycles that are adjusted to the time allocation and topic chosen. Based on the findings of the study, it can be concluded that the implementation of Prezi media can improve understanding of English class 2B material, Primary School Teacher Education Study Program. This increase was shown by the achievement of the average understanding of the concept of the first cycle of 73 with $69 \%$ completeness and in the second cycle of 83 with $94 \%$ completeness. So it can be concluded that there has been an increase of $25 \%$. This shows that the application of the learning model using this Prezi media can improve students' understanding.
\end{abstract}

Keywords: English learning, Prezi learning model, Prezi media

\begin{abstract}
Abstrak
Penelitian ini bertujuan untuk mengetahui penerapan model pembelajaran dengan menggunakan prezi untuk meningkatkan pemahaman kursus bahasa Inggris. Penelitian ini dilakukan di Universitas PGRI Madiun pada Tahun Akademik 2017/2018. Subjek penelitian adalah siswa Pendidikan Guru Sekolah Dasar. Penelitian ini menggunakan desain penelitian tindakan kelas (Penelitian Tindakan Kelas) dengan dua siklus yang disesuaikan dengan alokasi waktu dan topik yang dipilih. Kesimpulan dalam penelitian ini adalah bahwa penerapan media prezi dapat meningkatkan pemahaman materi kelas 2B bahasa Inggris, Program Studi Pendidikan Guru Sekolah Dasar. Peningkatan ini ditunjukkan dengan pencapaian pemahaman rata-rata konsep siklus pertama 73 dengan ketuntasan 69\% dan pada siklus kedua 83 dengan ketuntasan $94 \%$. Maka dapat disimpulkan bahwa terjadi peningkatan sebesar 25\%. Hal ini menunjukkan bahwa penerapan model pembelajaran menggunakan media prezi ini dapat meningkatkan pemahaman siswa.
\end{abstract}

Kata kunci: Pembelajaran Bahasa Inggris, Model Pembelajaran Prezi, Media Prezi 


\section{A. INTRODUCTION}

Teaching and learning of English is one of the important factors in improving the ability of human resources in Indonesia. In the globalization era it is now very important to master English because a lot of science and technology are presented in English. However, not all students master English. As a result many students still have difficulty absorbing knowledge and technology from the west.

In general, students have a poor understanding of English courses. Students assume that English courses are difficult. Many factors make them do not understand English. As a result, many of them received poor grades. For this reason, interesting learning is needed so that they are more interested in participating in English learning. To help clarify the delivery of material, it is necessary to have the right learning media so that students are more motivated.

Learning media can stimulate students to be more effective. Learning media will facilitate students to receive or remember the material that has been delivered. Another benefit is to facilitate the lecturer in delivering the material, because it can be directed directly to students. Therefore, the use of learning media can stimulate students to learn. The accuracy in choosing learning media that will be used in the teaching and learning process is very influential on the effectiveness of achieving the learning objectives to be achieved.

Learning media is very varied along with the rapid development of science and technology. One of them is the use of Prezi is an interactive and internet-based learning media that has a slide with the Zooming User Interface (ZUI) view. This learning media is a new breakthrough in learning, where the Prezi media can be used as a tool to explore and share ideas on virtual canvas. This Zooming User Interface (ZUI) display allows users to Prezi to zoom in and out on their presentation media. In addition the Prezi is used to make presentations in linear form or in the form of mind maps. In this Prezi media, text, images, videos, and other presentation media are placed on the presentation canvas and can be grouped into the frame provided.

From the description above, it is important to conduct research that focuses on the use of innovative learning media so that students' understanding of English learning increases. In this study Prezi media was used to improve understanding of English learning. 
Al-Lisan. Journal Bahasa \& Pengajarannya

ISSN 2442-8965 \& E ISSN 2442-8973

Volume 4 Nomor 1- Februari 2019

http://journal.iaingorontalo.ac.id/index.php/al

Learning is a process of creating conducive conditions for interaction between teaching and learning between teachers, students, and other learning components to achieve certain goals. (Rusman, et al, 2012: 15-16).

Gagne and Briggs (in Arsyad, 2011: 4) define learning media implicitly, namely a tool that is physically used to convey the content of teaching material, which consists of books, tape recorders, cassettes, video cameras, video recorders, films, slides (picture frames), photos, pictures, graphics, television, and computers. In other words, the media is a component of learning resources or physical vehicles that contain instructional material in the student environment that can stimulate students to learn.

Tarr (in Embi, 2011: 129) argues that Prezi media has the advantage that (1) has more factors than other slides, (2) it does not need to move from one slide to another. Enough with one large canvas that can be inserted with images, ideas, data, and so on. So for presentations with Prezi you don't need lots of slides, just 1 slide, (3) it's easy to combine images, sounds and videos in one view, (4) it's very easy to use.

The learning model with Prezi media is a new innovation in the world of information technology-based education. Prezi media can display an idea or idea in an interrelated view in a slide show with another slide. In this case, the Prezi media can focus on the desired slides so that it can facilitate understanding the contents of each slide. The presence of zoom out and zoom in features can make students become more interested in following English learning and students are easier to capture material so that student achievement is better.

\section{B. RESEARCH METHOD}

This research was conducted at the PGRI University of Madiun in the Academic Year of 2017/2018. The research subjects were students of Primary School Teacher Education. Research time starts from preparation to preparation of classroom action research reports starting from May 2018.

This study uses a classroom action research design that is used to solve learning problems in the classroom. In general, this study aims to improve the understanding of students of the Primary School Teacher Education study program on English language courses using Prezi media.

According to Kemmis and Mc Taggart in (Fitrianti, 2016: 22-23) there are four components in a cycle including: (1) planning, (2) action, (3) observation, and (4) 
Al-Lisan. Journal Bahasa \& Pengajarannya

ISSN 2442-8965 \& E ISSN 2442-8973

Volume 4 Nomor 1- Februari 2019

http://journal.iaingorontalo.ac.id/index.php/al

reflection. After a cycle has been implemented and reflected, then it is followed by replanning carried out in a separate cycle.

Data collection techniques in this study are tests and non-tests. Data collection techniques are how to obtain the data needed. According to Sugiyono (2012: 193) "Data collection techniques are the most strategic step in research because the aim of the research is to obtain data." This study uses a test with written techniques in the form of evaluation sheets done after learning English using Prezi which aims to measure understanding students are held at each meeting in each cycle. Non-test techniques are observation. Data from observations and researcher notes were analyzed descriptively to determine the quality of the teaching and learning process. To find out the improvement of learning outcomes is done by comparing the scores of students with previous tests. Student understanding data is analyzed on cognitive aspects. Data analysis for cognitive aspects was done by descriptive statistical analysis and gain score. The level of mastery of the material is analyzed by gain score by determining the gain score normalized.

According to Hake 1999 (in Yuliati, 2005: 92) the normalized gain score (9) is a good method for analyzing the results of the pre-test and post-test. Gain score is a good indicator to show the level of effectiveness of learning that is carried out in terms of the pre-test and post-test scores. According to Hake, the gain score normalized can be determined by the formula:

$$
<g>=\frac{\left(<S_{f}>-<S_{i}>\right)}{\left(100-<S_{i}>\right)}
$$

(Hake in Yuliati, 2005: 92)

Information :

$<$ g $>$ : gain score normalized

S_f : post-test mean score

S_i : average pre-test score

Gain score category:

g-high $\quad$ : with $(<\mathrm{g}>)>0.7$

g-medium: with $0.7 \geq(<\mathrm{g}>) \geq 0.3$

g-low : with $(<\mathrm{g}>)<0.3$ 


\section{Findings}

Pre-Action Findings

1. Understanding of English language material for students of Elementary School Teacher Education study programs is still lacking. This is reflected in the results of Midterm test, only a few who scored above 60, and others still under 60.

2. Students are less active both in the learning process and in working on the given questions. They did not dare to ask questions. Students are less concentrated in participating in learning. At the beginning of learning students seemed to concentrate on learning. But that didn't last long. Many students don't pay attention, there are those who play cell phones while learning takes place.

3. Lecturers still use power point media when learning. The learning method applied by the lecturer is lecture.

\section{Data Cycle I Exposure}

Based on the results of the observation, the data obtained from the observations of the lecturers' actions were obtained from the learning implementation sheet. The success of the lecturers' actions in learning in cycle $\mathrm{I}$ is $75 \%$. The results of the evaluation of understanding by applying the prezi media on learning cycle I can be seen in table 1. below:

Table 1. Data Frequency of Value of Postes Understanding Cycle I

\begin{tabular}{cccccc}
\hline No. & Interval & Frekuensi (fi) & Mid Score (xi) & fi.xi & Percentage (\%) \\
\hline 1. & $60-65$ & 5 & 62,5 & 313 & 16 \\
\hline 2. & $66-71$ & 4 & 68,5 & 274 & 13 \\
\hline 3. & $72-77$ & 15 & 74,5 & 1118 & 47 \\
\hline 4. & $78-83$ & 3 & 80,5 & 242 & 9 \\
\hline 5. & $84-89$ & 4 & 86,5 & 346 & 13 \\
\hline 6. & $90-95$ & 1 & 93,5 & 94 & 3 \\
\hline \multicolumn{7}{r}{ Total } & $\mathbf{3 2}$ & $\mathbf{4 6 6}$ & $\mathbf{2 3 8 5}$ & $\mathbf{1 0 0}$ \\
\hline Average Class & $\mathbf{= 7 3}$ & & & \\
\hline Completeness & $\mathbf{6 9 \%}$ & $\mathbf{6 9}$ & & & \\
\hline Top Value & $\mathbf{9 0}$ & $\mathbf{6 2}$ & & \\
\hline Lowest Value & $\mathbf{6 2}$ &
\end{tabular}


Al-Lisan. Journal Bahasa \& Pengajarannya

ISSN 2442-8965 \& E ISSN 2442-8973

Volume 4 Nomor 1- Februari 2019

http://journal.iaingorontalo.ac.id/index.php/al

A summary of data on the pre-test results of understanding the concept of students in cycle I can be seen in table 2. below:

Table 2. Percentage of Learning Completeness

of Students in the Pre-test of Cycle I

\begin{tabular}{cccc}
\hline Study Completeness & Students & All Student & Percentage \\
\hline Complete Study & 6 & 32 & $19 \%$ \\
\hline Not Complete Learning & 26 & 32 & $81 \%$ \\
\hline
\end{tabular}

The following is a summary of post-test understanding data in cycle I can be seen in the table below:

Table 3. Percentage of Student Completeness

in Post-Test Cycle I

\begin{tabular}{cccc}
\hline Study Completeness & Students & All Student & Percentage \\
\hline Complete Study & 23 & 32 & $72 \%$ \\
\hline Not Complete Learning & 9 & 32 & $28 \%$
\end{tabular}

Students concept comprehension tests were carried out at the beginning and end of cycle I. Based on these data, a percentage of students' understanding of the concept of grade $2 \mathrm{~B}$ in the first cycle can be compiled in table 4 . below:

Table 4. Achievement of students' understanding in cycle I

\begin{tabular}{ccc}
\hline Average Pretest & Average Post-test & Gain Score \\
\hline 66 & 75 & 0,26 \\
\hline
\end{tabular}

\section{Cycle II Data Exposure}

Observation activities were carried out by observers. Recapitulation of the results of observations of lecturers' actions was $76.59 \%$. The results of evaluation of understanding of future tense material by applying prezi media on learning cycle II can be seen in table 6 . below :

Table 6. Data Frequency of Cycle II Postes Understanding Value

\begin{tabular}{cccccc}
\hline No. & Interval & Frekuensi (fi) & Central Value (xi) & fi.xi & Percentage(\%) \\
\hline 1. & $68-72$ & 2 & 70,0 & 140 & 6 \\
\hline 2. & $73-77$ & 5 & 75 & 375 & 16 \\
\hline 3. & $78-82$ & 9 & 80 & 720 & 28 \\
\hline 4. & $83-87$ & 5 & 85 & 425 & 16 \\
\hline 5. & $88-92$ & 9 & 90 & 810 & 28 \\
\hline
\end{tabular}


Al-Lisan. Journal Bahasa \& Pengajarannya

ISSN 2442-8965 \& E ISSN 2442-8973

Volume 4 Nomor 1- Februari 2019

http://journal.iaingorontalo.ac.id/index.php/al

\begin{tabular}{lccccc}
\hline \multicolumn{2}{c}{$93-97$} & 2 & 95 & 190 & 6 \\
\hline \multicolumn{1}{c}{ Total } & & $\mathbf{3 2}$ & $\mathbf{4 9 5}$ & $\mathbf{2 6 6 0}$ & $\mathbf{1 0 0}$ \\
\hline Average Class & $\mathbf{9 7 3}$ & & & \\
\hline Completeness & $\mathbf{6} \mathbf{6 9 \%}$ & & & \\
\hline Top Value & $\mathbf{= 9 0}$ & & & \\
\hline Lowest Value & $\mathbf{= 6 2}$ & & & & \\
\hline
\end{tabular}

The description of the data obtained from the second cycle of the application of the learning model using prezi media is as follows.

Table 7. Percentage of Student Completeness in the Pre-test of Cycle II

\begin{tabular}{cccc}
\hline Study Completeness & $\sum$ Students & $\sum$ All Student & Percentage \\
\hline Complete Study & 22 & 32 & 69 \\
\hline Not Complete Learning & 10 & 32 & 31 \\
\hline
\end{tabular}

Summary of student post-test results in the second cycle can be seen in table 8 . below:

Table 8. Summary of Cycle II Student Post-test Results Data

\begin{tabular}{cccc}
\hline Study Completeness & $\sum$ Students & $\sum$ All Student & Percentage \\
\hline Complete Study & 30 & 32 & 94 \\
\hline Not Complete Learning & 2 & 32 & 6
\end{tabular}

Student understanding tests are carried out at the beginning and end of cycle II. Based on the data, the percentage of students' understanding of achievement in cycle II can be compiled in the table below.

Table 9. Achievement of Student Understanding in Cycle II

\begin{tabular}{ccc}
\hline Average of Pre-test & Average Post-test & Gain Score \\
\hline 54 & 83 & 0,62 \\
\hline
\end{tabular}

Based on table 9. above it can be seen that the calculation of the gain score in cycle II is 0.62 . The gain score shows that learning with media prezi has a very good success rate because it is included in the g-medium level.

Learning activities in cycle II are carried out based on the findings in cycle I. From the findings, improvements are made so that the learning activities in cycle II run better than cycle I. 
The development of student learning comprehension from the initial conditions to the second cycle can be seen in the following table 10. below:

Table 10. Development of Student Learning Understanding

\begin{tabular}{ccc}
\hline \multirow{2}{*}{ Action } & \multicolumn{2}{c}{ Total } \\
\cline { 2 - 3 } & Student Complete & Percentage (\%) \\
\hline Pre Action & 6 & 19 \\
\hline Cycle 1 & 22 & 69 \\
\hline Cycle II & 30 & 94 \\
\hline
\end{tabular}

\section{Discussions}

Based on data analysis conducted, in the first cycle showed an average test score of 75 with completeness of $72 \%$. In this first cycle, some students have not been able to achieve classical completeness. The factors that led to the achievement of classical completeness in the first cycle was due to (1) there were still few students who dared to ask questions, (2) there were still some students who played mobile phones during the learning process, (3) there were several students who were crowded especially those who sat behind, (4) during the delivery of the material, there were still students who did not pay attention, (5) there were some students who were not actively discussing the practice questions, (6) the ability of students to present the answers was low.

In the second cycle the average score of understanding increased to 83 with a classical completeness of $94 \%$. This shows that the application of learning media using this prezi media can improve students' understanding. The increasing understanding of students in the second cycle was due to the increase in student activity. This increase was marked by (1) the discussion went well, (2) students no longer played cell phones during the learning process, (3) students took the lecturers' explanations well.

The level of effectiveness of learning in this study was calculated using the gain score. Gain score increased from cycle 1 by 0.26 to 0.62 in cycle II. This shows that learning using media prezi can improve students' understanding of the material. 
Al-Lisan. Journal Bahasa \& Pengajarannya

ISSN 2442-8965 \& E ISSN 2442-8973

Volume 4 Nomor 1- Februari 2019

http://journal.iaingorontalo.ac.id/index.php/al

D. CONCLUSIONS

Based on the findings of the study, it can be concluded that the application of prezi media can improve understanding of English language material in class $2 \mathrm{~B}$, the Primary School Teacher Education Study Program. This increase was shown by the achievement of the average understanding of the concept of the first cycle of 75 with a completeness of $72 \%$ and in the second cycle of 83 with $94 \%$ completeness.

b. Suggestion

The results of this study have not fulfilled the actual objectives so it is necessary to include discussion of research findings based on research findings and existing theories. In addition, research needs to be done by developing media prezi with all teaching material in 1 semester, in order to produce a better understanding. 
Al-Lisan. Journal Bahasa \& Pengajarannya

ISSN 2442-8965 \& E ISSN 2442-8973

Volume 4 Nomor 1- Februari 2019

http://journal.iaingorontalo.ac.id/index.php/al

\section{REFERENCES}

Arsyad, Azhar. 2011. Media Pembelajaran. PT Raja Grafindo Persada: Jakarta

Embi, Muhammad. 2011. Aplikasi Web 2.0 dalam Pengajaran dan Pembelajaran. Selangor: Universiti Kebangsaan Selangor.

Fitrianti. 2016. Sukses Profesi Guru dengan Penelitian Tindakan Kelas. Deepublish: Yogyakarta.

Rusman, dkk. 2012. Pembelajaran Berbasis Teknologi Informasi dan Komunikasi: Mengembangkan Profesionalitas Guru. PT. Raja Grafindo Persada: Jakarta.

Sugiyono. 2012. Metode Penelitian Kuantitatif Kualitatif dan R\&D. Alfabeta: Bandung. 